\title{
Influence of Fibrolytic Enzymes Supplementation on Lactation Performance of Ossimi Ewes
}

\section{Gamal Ahmed Mousa*, Masouda A. Allak, Ola G.A. Hassan

\author{
Animal Production Department, Faculty of Agriculture, Fayoum University, Egypt.
}

\begin{abstract}
Fibrolytic enzymes can also enhance the utilization of feedstuff by increasing fiber digestion and degradation through increasing microbial communities in the rumen and reducing fluid viscosity thus this study aims to evaluate the effects of dietary fibrolytic enzymes supplementation on the performance of lactating Ossimi ewes. Twenty-one days postpartum 15 lactating Ossimi ewes $\left(41 \pm 1 \mathrm{~kg}\right.$ and at $3^{\text {rd }}$ to $4^{\text {th }}$ lactation season) were divided into three groups randomly (5 animals each). The $1^{\text {st }}$ group (G1) was kept as control and fed on $50 \%$ concentrates feed mixture (CFM), $25 \%$ Egyptian clover (EC), and $25 \%$ rice straw (RS). The $2^{\text {nd }}$ group (G2) was fed on a control diet with locally produced enzyme (LPE) at a concentration of $2 \mathrm{~g} / \mathrm{kg}$ DM. The $3^{\text {rd }}$ group (G3) was fed on a control diet with commercial fibrolytic enzyme (POLYZYME $)$ at a concentration of $2 \mathrm{~g} / \mathrm{kg}$ DM. The results revealed increases $(\mathrm{P} \leq 0.05)$ of crude fiber $(\mathrm{CF})$ and crude protein $(\mathrm{CP})$ digestibility in $\mathrm{G} 2$ and $\mathrm{G} 3$ diets compared to G1. The G2 and G3 increased (P $\leq$ 0.05 ) starch value (SV) and total digestible nutrient (TDN). Milk production yield (MPY) and $4 \%$ fat corrected milk $(\mathrm{FCM})$ were increased $(\mathrm{P} \leq 0.05)$ in $\mathrm{G} 2$ and $\mathrm{G} 3$. Insignificant increases were recorded in milk compositions percentage among all the tested groups. Feed conversion of TDN and SV decreased $(\mathrm{P} \leq 0.05)$ in G1 compared to G2 and G3 diets. Biochemical analysis revealed significant differences among all groups in overall means of glucose, where G3 was higher and all values within the normal range. From an economic point, the best net profit (L.E./head/63d) was recorded in $\mathrm{G} 2, \mathrm{G} 3$, and $\mathrm{G} 1$ diets.
\end{abstract}

Keywords | Lactating ewes, Digestibility, Milk yield, Milk composition, Blood serum

Received | July 12, 2021; Accepted | September 27, 2021; Published | December 01, 2021

*Correspondence | Gamal Ahmed Mousa, Department of Animal Production, Faculty of Agriculture, Fayoum University, Egypt; Email: gam02@fayoum.edu.eg Citation | Mousa GA, Allak MA, Hassan OGA (2022). Influence of fibrolytic enzymes supplementation on lactation performance of Ossimi ewes. Adv. Anim. Vet. Sci. 10(1): 27-34.

DOI | http://dx.doi.org/10.17582/journal.aavs/2022/10.1.27.34

ISSN (Online) | 2307-8316; ISSN (Print) | 2309-3331

Copyright $(\subseteq 2022$ Mousa et al. This is an open access article distributed under the Creative Commons Attribution License, which permits unrestricted use, distribution, and reproduction in any medium, provided the original work is properly cited.

\section{INTRODUCTION}

T he increases in feed prices particularly grains and declines in costs of locally produced enzymes have promoted the interest in the use of enzyme additives in lactating animal diets for increasing the utilization of nutrients and ensuring profitability and sustainability of livestock production activities (Beauchemin et al., 2008). By using enzymes with fibrolytic properties in animal feed, an increase in ruminal energy utilization was recorded, as these products increase the number of enzymes that are available for digesting higher amounts of fiber in the rumen (Vinici et al., 2003).

Biological treatment of agricultural products by fibrolytic enzymes plays an important role in the degradations of cellulose, hemicellulose, and pectin, in turn; simplify those compounds which increase nutrient digestibility in animals supplemented with these enzymes (Aboul-Fotouh et al., 2016). Cellulase enzyme is a complex multi-enzyme system acts to hydrolyze cellulose from agriculture by-product for producing simple glucose units (Smith, 1996), while pectinase enzyme act for breaking down polysaccharide pectin structure present in the cell wall constituents into galacturonic acid monomers (E1-Garhy et al., 2020a).

Several studies on enzymes that play an important role in lactating animals' diets reported an increase in yields of milk by $3-18 \%$ (Kholif et al., 2016, 2018; Morsy et al., 2016; Aboul-Fotouh et al., 2017; Azam et al., 2017; Tirado- 
González et al., 2018; Azzaz et al., 2019, 2020b; El-Garhy et al., 2020b). Thus, the current study aims to determine the influence of supplemented fibrolytic enzymes in lactating ewe's diet on digestibility of nutrients, milk yield, and composition, FCM yield, feed conversion, and some blood metabolites. In addition, an economic evaluation of the tested diets was carried out.

\section{MATERIALS AND METHODS}

\section{ETHICS APPROVAL}

Animal studies have been approved by the ethical committee. The research was performed following the ethical standard laid down in the 1996 declaration of Helsinki and its later amendments.

\section{LOCATION, HOUSING, AND TIME OF THE EXPERIMENT}

The current trial was performed at farm of Faculty of Agriculture while all analysis of this study were carried out at the laboratory of Animal Production Department, Fayoum University, Egypt, from January to March 2021. Ewes were kept outdoors with shelter during the day and housed in semi-open barn at night. They were maintained under the same managerial and environmental conditions. Ewes were healthy and clinically free of external and internal parasites. The lighting program by using light bulbs provided $13 \mathrm{~h}$ of light per day for each animal in the trial.

\section{Animals AND DieTs}

Fifteen lactating Ossimi ewes at the $3^{\text {rd }}$ to $4^{\text {th }}$ season were used for the current study. The ewes were chosen based on their weight with an average body weight of $41 \pm 1 \mathrm{~kg}$. They were divided into 3 groups of five ewes randomly 21 days postpartum. The experiment was designed to last for 63 days.

The $1^{\text {st }}$ group (control diet, G1) was fed on a diet of $50 \%$ concentrate feed mixture (CFM), 25\% Egyptian clover (EC), and $25 \%$ rice straw (RS). The $2^{\text {nd }}$ group (G2) was fed a control diet with locally produced enzyme (LPE) at a concentration of $2 \mathrm{~g} / \mathrm{kg}$ DM intake. The $3^{\text {rd }}$ group (G3) was fed a control diet with a commercial fibrolytic enzyme (POLYZYME ${ }^{\circledast}$ ) at a concentration of $2 \mathrm{~g} / \mathrm{kg}$ DM intake. The two pectinolytic enzymes were supplemented to the diets at the optimum rates as recommended by the manufacturer (IBEX international LTD). The CFM consisted of $55 \%$ yellow corn, $22.5 \%$ wheat bran, $20 \%$ soybean meal, $1 \%$ limestone, $0.5 \%$ dicalcium phosphate, $0.5 \%$ premix, and $0.5 \% \mathrm{NaCl}$ on dry matter (DM) basis. The nutritional requirements of ewes were calculated according to NRC (1985) and fresh water was available freely during all the day time to the animals.

\section{SOURCE AND CHARACTERIZATION OF ENZYMES}

The locally produced enzyme (LPE) was extracted from Aspergillus niger which was grown onto sugar beet pulp media. Each gram contains 2500 units of cellulase and 450 units of pectinase. The POLYZYME ${ }^{\circledR}$ is a commercial enzyme that was purchased from IBEX International LTD company (United Kingdom), Egypt. Each gram contains 3000 units of cellulase and 500 units of pectinase.

The carboxymethyl-cellulase (CMC) and pectinase activities for the LPE and POLYZYME ${ }^{\varpi}$ enzymes were determined as recommended by Mandels et al. (1974) and Buga et al. (2010). Cellulase unit was determined as the quantity of enzyme that liberates reducing sugar at $(1 \mu \mathrm{mol} /$ $\mathrm{ml} / \mathrm{min}$ ) under examination conditions (Miller, 1972). While pectinase unit was determined as the quantity of enzyme that produces $1 \mu \mathrm{mol}$ of D-galacturonic acid $/ \mathrm{ml} /$ min at $\mathrm{pH} 5.0$ and $40^{\circ} \mathrm{C}$ (Soares et al., 1999).

\section{Digestibility TRIAL}

A digestibility trial was performed at the end of the lactation period. Digestibility of nutrients was determined using the acid insoluble ash (AIA) method as reported by Van Keulen and Young (1977). Samples of polled ewe's feces were combined daily for seven days. Feces were dried for $24 \mathrm{~h}$ at $70^{\circ} \mathrm{C}$, crushed, dried for 3 hours at $105^{\circ} \mathrm{C}$, weighed, and stored in bottles for the chemical analysis.

\section{BLOOD SAMPLES}

Two blood samples $(5 \mathrm{ml})$ were taken from jugular vein of each animal in the trial through the last 2 days of each month of the experimental period (63 days) before morning feeding. A sample of blood was collected from the jugular vein into dry clean glass tubes per animal. Blood samples have been centrifuged for 15 minutes at $3500 \mathrm{rpm}$ for serum separation. Serum was stored at $-20^{\circ} \mathrm{C}$ for chemical analysis.

\section{MiLK PRODUCTION}

The method of hand milking was used for calculating milk yield. Ewes were milked twice daily at 7:00 am and 7:00 pm by milking half udder while the other half udder lift for suckling young lambs as cited by El- Garhy et al. (2020b). Total milk yield and daily milk yield were estimated for each ewe in the trial period for 63 days. Six milk samples (300 $\mathrm{ml}$ each) were collected for each animal in the trial during the experimental period, milk samples were kept at $\left(-20^{\circ} \mathrm{C}\right)$ until analysis of milk components immediately after the experiment is over.

\section{SAMPle ANALYSis}

\section{FEeds AND Feces}

Samples (250 g on DM basis) of concentrate feed mixture, Egyptian clover, and rice straw were collected for chemical 
analysis while there were seven samples of feces were collected for each animal at the end of the trial. Samples for each animal were polled and examined for the percentage of dry matter (DM), crude protein (CP) by using the macro Kjeldahl method, ether extract (EE), crude fiber (CF), and ash contents according to AOAC (2009). The nitrogenfree extract (NFE) was determined using the following formula:

\section{Organic matter $(O M)-($ ether extract $(E E)+$ crude protein $(C P)+$ crude fiber $(C F))$}

The cell wall constituents as neutral detergent fiber (NDF), acid detergent fiber (ADF), and acid detergent lignin (ADL) were determined in feeds and feces concerning Goering and Van Soest (1970).

\section{BLOOD SERUM}

Commercial kits (Stanbio Laboratory, USA) were been used to analyze all blood serum metabolites according to the manufactures instruction and Spectrophotometer (T80 UV/VIS PG instrument Ltd, UK). The total protein that was determined by the biuret reaction as noted by the method of Armstrong and Carr (1964) and expressed as $\mathrm{g} / \mathrm{dl}$. Serum urea $(\mathrm{mg} / \mathrm{dl})$ was measured by using test kits according to Richard et al. (2011). Serum creatinine (mg/ dl) was determined by using test kits as reported by Spierto et al. (1979). Serum aspartate aminotransferase (AST, IU/L) and Alanine aminotransferase (ALT, IU/L) were measured by using test kits as mentioned by Reitman and Frankel (1957). Serum glucose (mg/dl) was determined at the wavelength of $500 \mathrm{~nm}$ by using test kits as investigated by Howanitz and Howantiz (1984). The concentration of serum cholesterol $(\mathrm{mg} / \mathrm{dl})$ was measured as investigated by Burtis et al. (2006).

\section{Milk AnALYsis}

The total solids, protein, and ash of milk samples were determined by AOAC (2009). The milk fat samples were estimated by Gerber's according to Bradley et al. (1992). Solids not fat were calculated by the following formula:

$$
\text { (The total solids - fat \%) }
$$

Lactose content was calculated by difference by the following formula:

$$
\text { (Solids not fat - (protein\% + ash \%) }
$$

The 4\% FCM was calculated by the equation of Gaines (1928) as the following:

$$
F C M=0.4 M+15 F
$$

Where; $\mathrm{M}=$ milk yield (gram/day), $\mathrm{F}=$ amount of fat $=$ (milk yield $\mathrm{x}$ fat \%).

\section{Simple economic EVAluation}

Simple financial returns of the tested diets were calculated as; the price of $1 \mathrm{~kg}$ of milk of the tested ewes was $12 \mathrm{~L} . \mathrm{E}$ (Egyptian pound). The cost of 1 ton DM of CFM (93.56\% $\mathrm{DM}), \mathrm{EC}(15 \% \mathrm{DM})$, and RS (91.8\% DM) were 6000, 350, and 1450 L.E., respectively. Prices of $1 \mathrm{~kg}$ of LPE and POLYZYME ${ }^{\circledast}$ enzymes were 60 and 180L.E, respectively.

\section{STATISTICAL ANALYSis}

The obtained data of nutrient digestibility, feed conversion, biochemical blood parameters, and milk compositions were statistically analyzed by one-way analysis of variance (ANOVA) to test the significance among means through the general linear model procedure reported by SPSS (2007) according to this model:

$$
Y_{i j}=\mu+T_{i}+e_{i j}
$$

Where; $Y_{i j}$ is observed traits, $\mu$ is the overall mean, $T_{i}$ is the experimental group and $\mathrm{e}_{\mathrm{ij}}$, is the random error. The significant differences among treatment groups were tested by using Duncan's Multiple Test (Duncan, 1955).

\section{RESULTS AND DISCUSSION}

\section{Chemical COMPOSITION OF THE EXPERIMENTAL} DIETS

Chemical composition and cell wall constituents on DM basis of CFM, EC, and RS that were used in the current study are shown in Table 1 . The chemical composition showed that RS was the highest levels of crude fiber, ash, NDF, ADF, hemicellulose, and cellulose compared to CFM and EC.

Table 1: Chemical composition of feed ingredients (on \%DM basis).

\begin{tabular}{llll} 
Item & CFM & EC & RS \\
OM & 96.64 & 82.50 & 77.45 \\
CP & 16.73 & 15.40 & 1.95 \\
EE & 2.86 & 2.70 & 1.39 \\
CF & 4.83 & 23.80 & 45.23 \\
\hline NFE & 72.22 & 40.60 & 28.88 \\
Ash & 3.36 & 17.5 & 22.55 \\
\hline NDF & 16.13 & 48.75 & 70.55 \\
\hline ADF & 5.54 & 38.85 & 55.14 \\
ADL & 0.86 & 9.69 & 5.66 \\
\hline Hemicellulose & 10.59 & 9.90 & 15.41 \\
\hline Cellulose & 4.68 & 29.16 & 49.48 \\
\hline
\end{tabular}

Hemicellulose $=$ NDF-ADF; Cellulose $=$ ADF-ADL; CFM, concentrate feed mixture. Each value is a mean of 5 samples. 


\section{DigeSTIBILITY AND NUTRITIVE VALUES}

The results of Table 2 showed that diets supplemented with LPE (G2) and POLYZYME ${ }^{\otimes}$ (G3) significantly $(\mathrm{P} \leq 0.05)$ increased $\mathrm{CP}$ and $\mathrm{CF}$ digestibility compared to (G1) control. There was a non-significant increase between all the tested diets concerning DM, OM, EE, and NFE digestibility. Moreover, a non-significant increase was recorded in $\mathrm{G} 2$ and $\mathrm{G} 3$ diets concerning $\mathrm{CP}$ and $\mathrm{CF}$ digestibility. Using enzymes with fibrolytic properties in animal feed can increase ruminal energy utilization as these products increase the number of enzymes that are available for digesting more fiber in the rumen (Vinici et al., 2003). Fibrolytic enzymes can enhance the utilization of feedstuff by increasing fiber digestion and degradation through increasing microbial communities in the rumen and reducing fluid viscosity of (Morgavi et al., 2000; Adesogan et al., 2014). The current results were nearly similar to those obtained by (Aboul-Fotouh et al., 2017; Arif et al., 2019; Khattab et al., 2019; El-Garhy et al., 2020b) who observed an increase in total tract digestibility of DM and OM when using fibrolytic enzymes in diets. The increased nutritive value of diets by the supplementation with LPE and POLYZYME ${ }^{\circledR}$ may be attributed to the availability of a readily great amount of fermentable carbohydrate liberated by the enzymatic action on cellulose and pectin of diets causing the improvement in nutrients digestibility. These results were following those obtained by El- Garhy et al. (2020b) who reported that dietary fibrolytic enzymes supplementation to lactating buffaloes contributed to significantly improved nutrients digestibility and nutritive value of the tested diets compared with animals of control.

Table 2: Impact of fibrolytic enzymes on digestion coefficients and nutritive values of the experimental groups of lactating Ossimi ewes.

\begin{tabular}{|c|c|c|c|c|}
\hline \multicolumn{5}{|c|}{ The experimental groups } \\
\hline Item & G1 & G2 & G3 & $\pm \mathrm{SE}$ \\
\hline \multicolumn{5}{|c|}{ Nutrient digestibilities(\%) } \\
\hline DM & 69.05 & 71.51 & 71.22 & 0.68 \\
\hline $\mathrm{OM}$ & 69.33 & 70.84 & 70.09 & 0.67 \\
\hline $\mathrm{CP}$ & $63.76^{\mathrm{b}}$ & $65.95^{\mathrm{a}}$ & $65.73^{\mathrm{a}}$ & 0.87 \\
\hline $\mathrm{CF}$ & $61.42^{\mathrm{b}}$ & $65.78^{a}$ & $65.49^{\mathrm{a}}$ & 0.81 \\
\hline $\mathrm{EE}$ & 58.81 & 60.19 & 61.09 & 0.95 \\
\hline NFE & 68.81 & 70.26 & 69.36 & 0.53 \\
\hline \multicolumn{5}{|c|}{ Nutritive values } \\
\hline TDN (\%) & $61.16^{\mathrm{c}}$ & $64.93^{\mathrm{a}}$ & $63.22^{\mathrm{b}}$ & 0.55 \\
\hline SV $(\%)$ & $53.99^{c}$ & $57.71^{\mathrm{a}}$ & $56.02^{\mathrm{b}}$ & 0.54 \\
\hline DCP (\%) & 8.03 & 8.68 & 8.21 & 0.13 \\
\hline
\end{tabular}

$\mathrm{a}, \mathrm{b}$, and $\mathrm{c}$ : Means in the same row with different superscripts are significantly different $(\mathrm{P} \leq 0.05)$. Each value is a mean of 5 samples.

The nutritive values of the experimental groups as total digestible nutrients (TDN), digestible crude protein
(DCP), and starch value (SV) were revealed in Table 2. The supplemented diets (G2 and G3) significantly $(\mathrm{P} \leq 0.05)$ increased SV and TDN compared to the G1 diet (control). Moreover, the diet of G2 significantly $(\mathrm{P} \leq 0.05)$ increased TDN and SV\% compared to the G3 diet. There were nonsignificant increases between all the experimental groups in DCP.

\section{FEED INTAKE AND FEED CONVERSION}

Daily feed intake of lactating Ossimi ewes in Table 3 revealed non-significant differences between the tested groups. Aboul-Fotouh et al. (2017); Khattab et al. (2019); El-Garhy et al. (2020b) mentioned that there are no effects on daily feed intakes of DM when enzymes were added to an animal's diet.

Table 3: Fibrolytic enzymes effect on feed intake and feed conversion in lactating Ossimi ewes.

\begin{tabular}{lllll} 
Items & \multicolumn{3}{c}{ The experimental groups } & \multirow{2}{*}{ SE } \\
\cline { 2 - 4 } & G1 & G2 & G3 & \\
Average yield of 4\% & $535.83^{\mathrm{b}}$ & $678.81^{\mathrm{a}}$ & $706.92^{\mathrm{a}}$ & 25.42 \\
FCM (g/head/day) & & & & \\
\hline Average daily feed intake/head & & & \\
DM, g & 1280 & 1310 & 1300 & 0.17 \\
\hline TDN,g & 782.85 & 850.58 & 821.86 & 0.45 \\
\hline SV, g & 691.07 & 756.00 & 728.26 & 0.30 \\
\hline DCP, g & 102.78 & 113.71 & 106.73 & 0.20 \\
\hline Feed conversion * & & & & \\
\hline DM/ g/g milk & 2.39 & 1.93 & 1.84 & 0.11 \\
\hline TDN/g/g milk & $1.46^{\mathrm{a}}$ & $1.25^{\mathrm{b}}$ & $1.16^{\mathrm{b}}$ & 0.04 \\
\hline SV/ g/g milk & $1.29^{\mathrm{a}}$ & $1.11^{\mathrm{b}}$ & $1.03^{\mathrm{b}}$ & 0.16 \\
\hline DCP/g/g milk & 0.19 & 0.17 & 0.15 & 0.01 \\
\hline
\end{tabular}

$\mathrm{a}$ and $\mathrm{b}$ : Means in the same row with different superscripts are significantly different $(\mathrm{P} \leq 0.05)$. *, Feed conversion was determined depending on daily FCM. Each value is a mean of 5 samples.

Daily feed conversion of lactating Ossimi ewes in Table 3 , revealed that TDN and SV in the diet of G1 were significantly $(\mathrm{P} \leq 0.05)$ decreased compared to $\mathrm{G} 2$ and $\mathrm{G} 3$ diets. In contrast, there were non-significant differences in feed conversions of DM and DCP between the tested diets. Moreover, there were non-significant differences concerning feed conversions between G2 and G3. The current results were consistent with the findings of Mohamed et al. (2013) who mentioned that adding exogenous fibrolytic enzymes in diets of lactating animals had decreased $(\mathrm{P} \leq 0.05)$ feed conversions compared to control not supplemented diets. El-Garhy et al. (2020b) found that adding enzymes to buffalo's diet decreased $(\mathrm{P} \leq 0.05)$ feed conversions compared. Moreover, the decrease in feed conversions by ewes supplemented with enzymes may be attributed to the improvement of the feed nutrients digestibility. 
Table 4: Influence of fibrolytic enzymes supplemented diets on some blood parameters of lactating Ossimi ewes.

\begin{tabular}{|c|c|c|c|c|c|c|}
\hline \multirow[t]{2}{*}{ Items } & \multicolumn{3}{|c|}{ The experimental groups } & \multirow[t]{2}{*}{$\pm \mathrm{SE}$} & \multirow[t]{2}{*}{ Physiological range } & \multirow{2}{*}{$\begin{array}{l}\text { References of physiological } \\
\text { range }\end{array}$} \\
\hline & G1 & G2 & G3 & & & \\
\hline Total protein $(\mathrm{g} / \mathrm{dl})$ & 7.2 & 6.4 & 6.6 & 0.27 & $6.1-7.5$ & Boyd (2011) \\
\hline Creatinine (mg/dl) & 1.11 & 1.17 & 1.12 & 0.04 & $0.7-1.5$ & \\
\hline $\operatorname{Urea}(\mathrm{mg} / \mathrm{dl})$ & 34.5 & 33.92 & 33.75 & 0.87 & $10-50$ & Kaneko (1989) \\
\hline AST (IU/L) & 82 & 84 & 81 & 4.7 & Up to 275 & \\
\hline ALT (IU/L) & 19 & 25 & 22.7 & 1.66 & $30-5$ & \\
\hline Glucose( mg/dl) & $57.67^{c}$ & $63.33^{\mathrm{b}}$ & $67^{a}$ & 1.23 & $48-76$ & Boyd (2011) \\
\hline Cholesterol (mg/dl) & 77 & 81 & 78 & 2.35 & $65-136$ & \\
\hline
\end{tabular}

a, b, and c: Means in the same row with different superscripts are significantly different $(\mathrm{P} \leq 0.05)$. Each value is a mean of 5 samples.

\section{BLOOD SERUM}

Influence of LPE and POLYZYME ${ }^{\circledR}$ enzymes supplemented diets on serum total protein, creatinine, urea, AST, ALT, cholesterol, and glucose of lactating Ossimi ewes were shown in Table 4. The addition of fibrolytic enzymes to the ewes' diet showed significant $(\mathrm{P} \leq 0.05)$ increases in glucose concentration. The diets supplemented with POLYZYME ${ }^{\circledast}$ (G3) had increased $(\mathrm{P} \leq 0.05)$ serum glucose concentration compared to LPE (G2). Moreover, the diets which were supplemented with fibrolytic enzyme had recorded a reduction in total protein and urea concentrations compared to control. There were non-significant differences between all experimental groups in overall means of blood concept glucose and all values of serum biochemical parameters in the current study were within the normal range. Arif et al. (2019) reported that increasing the concentration of blood glucose may be attributed to the action of enzymes that release soluble sugars in animals fed on diets supplemented with the enzyme. Increasing the concentration of blood glucose in animals may be due to a high fermentable carbohydrate which increased concentrations of volatile fatty acids especially propionate which is the precursor of glucose synthesis as cited by El-Garhy et al. (2020b). The lower serum total protein and urea concentration in the current study may be attributed to high protein utilization by lactating Ossimi ewes supplemented with fibrolytic enzymes. El-Garhy et al. (2020b) reported reductions in serum urea concentrations that may be attributed to the use of urea for protein synthesis on the rumen hepatic pathway.

\section{MILK YIELD AND COMPOSITION}

Table 5 revealed that diets supplemented with enzymes (G2 and G3) significantly (P $\leq 0.05)$ increased milk yield and FCM yield compared to (G1) control. The control group (G1) showed the lowest milk yield followed by G3. The highest value was recorded in G2. In addition, there were non-significant increases in milk yield and FCM yield between groups supplemented with fibrolytic enzymes (G2 and G3). Furthermore, adding LPE increased milk yield by $25.56 \%$ and FCM by $26.68 \%$, while adding POLYZYME increased milk yield by $24.74 \%$ and FCM yield by $31.9 \%$.
In contrast, there was a non-significant increase in all the experimental groups in milk compositions percentage. While G2 and G3 diets significantly $(\mathrm{P} \leq 0.05)$ increase milk components yield of total solids, SNF, fat, total protein, and lactose. There were non-significant increases in all the experimental groups in ash yield. Many kinds of research on enzymatic supplementation to lactating animals diets shown an increase in milk yields by $3-18 \%$ (Kholif et al., 2016, 2018; Morsy et al., 2016; Aboul-Fotouh et al., 2017; Azam et al., 2017; Tirado-González et al., 2018; Azzaz et al., 2019, 2020b; El-Garhy et al., 2020b). The results of 4\% FCM yield were in agreement with the findings obtained by (Aboul-Fotouh et al., 2017; Arif et al., 2019; Khattab et al., 2019; El-Garhy et al., 2020b) who reported an increase in FCM yield for lactating animals fed fibrolytic enzymes compared with control animals. The current results may reflect the influence of fibrolytic enzymes as the current results reported greater amounts of digested fiber in the rumen that provide more acetate for fatty acid synthesis. Moreover, El-Garhy et al. (2020b) reported that the enhancement in milk yield may be attributed to the large amounts of nutrients absorbed in the rumen and gastrointestinal tract.

\section{A Simple ECONOMic EVAluAtion of THE TESTED} DIETS

Economic evaluations for the experimental groups are shown in Table 6. The net profit (L.E./head/63day) was increased for lactating Ossimi ewes fed on diets supplemented with LPE and POLYZYME ${ }^{\circledast}$ enzymes. The best net profit(L.E./head/63 days) was recorded bylactating Ossimi ewes fed a diet supplemented with LPE followed by those fed a diet supplemented with POLYZYME then control diet. The cost of DM consumed by ewes fed on diet with adding POLYZYME ${ }^{\oplus}$ was higher than the other tested diets as the price of $1 \mathrm{~kg}$ of POLYZYME was higher. Aboul-Fotouh et al. (2017) and El-Garhy et al. (2020b) mentioned that the economic values were increased for animals fed with diets supplemented with laboratory enzymes compared to commercial enzyme and control diets. The supremacy of diet (G2) regarding values of net profit may be due to the lower cost of LPE enzyme compared to POLYZYME ${ }^{\circledast}$. 
Table 5: Influence of fibrolytic enzymes supplemented diets on milk yield and composition of lactating Ossimi ewes.

\begin{tabular}{|c|c|c|c|c|}
\hline \multirow[t]{2}{*}{ Items } & \multicolumn{3}{|c|}{ The experimental groups } & \multirow[t]{2}{*}{$\pm \mathrm{SE}$} \\
\hline & G1 & G2 & G3 & \\
\hline Average milk yield (g/head/day). & $457^{\mathrm{b}}$ & $573.8^{\mathrm{a}}$ & $570.1^{\mathrm{a}}$ & 22.33 \\
\hline Average $4 \%$ Fat corrected milk yield ( $\mathrm{g} / \mathrm{head} /$ day) & $535.83^{\mathrm{b}}$ & $678.81^{\mathrm{a}}$ & $706.92^{\mathrm{a}}$ & 25.42 \\
\hline \multicolumn{5}{|l|}{ Milk compositions \% } \\
\hline Total solids & 14.68 & 14.93 & 15.62 & 0.32 \\
\hline Fat & 5.15 & 5.22 & 5.60 & 0.15 \\
\hline SNF & 9.53 & 9.71 & 10.02 & 0.30 \\
\hline Total protein & 3.75 & 3.71 & 4.03 & 0.12 \\
\hline Lactose & 5.07 & 5.27 & 5.31 & 0.21 \\
\hline Ash & 0.71 & 0.73 & 0.68 & 0.02 \\
\hline \multicolumn{5}{|l|}{ Milk components yield (g/head/day) } \\
\hline Total solids & $67.09^{\mathrm{b}}$ & $85.67^{\mathrm{a}}$ & $89.05^{\mathrm{a}}$ & 2.97 \\
\hline Fat & $23.54^{\mathrm{b}}$ & $29.95^{\mathrm{a}}$ & $31.93^{\mathrm{a}}$ & 1.24 \\
\hline SNF & $43.55^{\mathrm{b}}$ & $55.72^{\mathrm{a}}$ & $57.12^{\mathrm{a}}$ & 1.86 \\
\hline Total protein & $17.14^{\mathrm{b}}$ & $21.29^{\mathrm{a}}$ & $22.98^{\mathrm{a}}$ & 0.96 \\
\hline Lactose & $23.17^{b}$ & $30.24^{\mathrm{a}}$ & $30.27^{a}$ & 1.18 \\
\hline Ash & 3.24 & 4.19 & 3.88 & 0.17 \\
\hline
\end{tabular}

$\mathrm{a}$ and $\mathrm{b}$ : Means in the same row with different superscripts are significant $(\mathrm{P} \leq 0.05)$. Each value is a mean of 5 samples.

Table 6: Fibrolytic enzymes supplemented diets effect on economic evaluation of lactating Ossimi ewes.

\begin{tabular}{|c|c|c|c|}
\hline \multirow[t]{2}{*}{ Item } & \multicolumn{3}{|c|}{ The experimental groups } \\
\hline & G1 & G2 & G3 \\
\hline Milk yield (kg/head/63day) & 28.79 & 36.15 & 35.9 \\
\hline Dry matter consumed ( $\mathrm{kg} /$ head /63day $)$ & 80.64 & 82.53 & 81.9 \\
\hline Fibrolytic enzymes (g/head/63day) & 0 & 165.1 & 163.8 \\
\hline Price of one $\mathrm{kg}$ dry matter of the diet, L.E & 4 & 4.16 & 4.47 \\
\hline Cost of feed consumed (L.E / head / 63 day ) & 322.56 & 343.32 & 366.09 \\
\hline Total profit, L.E* & 345.5 & 433.8 & 430.8 \\
\hline Net profit, L.E $E^{* *}$ & 22.94 & 90.48 & 64.71 \\
\hline
\end{tabular}

*,Total profit, L.E= Milk yield ( $\mathrm{kg} / \mathrm{head} / 63$ days $) \times 12 \mathrm{~L} . \mathrm{E}$ (the price of one $\mathrm{kg}$ ewes milk). **, Net profit (L.E./ head $/ 63$ day) = Total revenue (L.E./ head/63day) - cost of feed consumed (L.E./ head/63day). Each value is a mean of 5 samples.

\section{CONCLUSIONS AND} RECOMMENDATIONS

Supplementation of diets of lactating Ossimi ewes with the LPE and POLYZYME ${ }^{\varpi}$ enzymes contributed to an increase of nutrient digestibility and significantly increased milk yield and FCM. In a simple economic study, the diet of LPE was the best one and all mean values of some blood serum metabolites were within the normal range.

\section{NOVELTY STATEMENT}

This study contributes to improving the nutrient digestibility, feeding values, feed conversion and milk production of Ossimi ewes using locally and commercial fibrolytic enzymes.

\section{AUTHOR'S CONTRIBUTION}

GAM,MAA, OAH conceived and designed the experiment. GAM, MAA, OAH took a part in experimenting. GAM preparation, writing, and editing the manuscript.

\section{STATEMENT OF CONFLICT OF INTEREST}

The authors have declared no conflict of interest.

\section{REFERENCES}

-Aboul-Fotouh GE, El-Garhy GM, Abd El-Mola AM, Mousa GA, Azzaz HH (2017). Effect of using some fibrolytic enzymes in the ration on lactating goats performance. Egypt. J. Nutr. Feeds, 20(2): 1-9. Special Issue. https://doi. org/10.21608/ejnf.2017.103671

-Aboul-Fotouh GE, El-Garhy GM, Azzaz HH, Abd El-Mola 
AM, Mousa GA (2016). Fungal cellulase production optimization and its utilization in goat's rations degradation. Asian J. Anim. Vet. Adv. J., 12; 824-831. https://doi. org/10.3923/ajava.2016.824.831

-Adesogan AT,Ma ZX, Romero JJ, Arriola KG (2014). Ruminant Nutrition Symposium: Improving cell wall digestion and animal performance with fibrolytic enzymes. J. Anim. Sci., 92: 1317-1330. https://doi.org/10.2527/jas.2013-7273

-AOAC (2009). Official methods of analysis of AOAC International, $18^{\text {th }} \mathrm{Ed}$. Association of Official Analytical chemists, Washington, D.C., USA.

-Arif M, Al-Sagheer AA, Salem AZM, Abd El-Hack ME, Swelum AA, Saeed M,Jamal M,Akhtar M (2019). Influence of exogenous fibrolytic enzymes on milk production efficiency and nutrient utilization in early lactating buffaloes fed diets with two proportions of oat silage to concentrate ratios. Livest. Sci., 219: 29-34. https://doi.org/10.1016/j. livsci.2018.11.007

-Armstrong WD, Carr CW (1964). Physiological chemistry, $3^{\text {rd }}$ Ed. Laboratory Directions Bures Publishing Co. Minneapolis, Minnesota, USA.

-Azam B, Tahir MN, Shahzad F, Abdul Ghaffar, Abbas G, Gohar M, Saima (2017). Exogenous fibrolytic enzymes addition in concentrate ration of lactating Nili Ravi buffaloes: Effects on milk production and diet digestibility. Pakistan J. Zool., 49: 1359-1364. https://doi.org/10.17582/journal. pjz/2017.49.4.1359.1364

-Azzaz, HH, Aboamer AA, Alzahar H, Abdo MM, Murad HA (2019). Effect of xylanase and phytase supplementation on goat's performance in early lactation. Pak. J. Biol. Sci., 22: 265-272. https://doi.org/10.3923/pjbs.2019.265.272

-Azzaz HH, Aboamer AA, Alzahar H, Hassaan NA, Murad HA (2020b). Effect of cellulases supplementation on milk yield and feed utilization by Baladi goats in early lactation. Int. J. Dairy Sci., 15: 48-53. https://doi.org/10.3923/ ijds.2020.48.53

- Beauchemin KA, Eriksen L, Nørgaard P, Rode LM (2008). Salivary secretion during meals in lactating dairy cattle. J. Dairy Sci., 91: 2077-2081. https://doi.org/10.3168/ jds.2007-0726

- Boyd JW (2011). The interpretation of serum biochemistry test results in domestic animal, In: Veterinary clinical pathology, Merck Sharp and Dohme Corp., a subsidiary of Merck and Co., Inc.

- Bradley RL, Arnold E, Barbano DM, Semerad RG, Smith DE, Vines BK, Case RA (1992). Chemical and physical methods. In: Standard methods for the examination of dairy products, mashall, R.T. (Ed.). Port city press, Baltimore, Washington. https://doi.org/10.1021/j100180a017

- Buga ML, Ibrahim S, Nok AJ (2010). Partially purified polygalacturonase from Aspergillus niger (SA6). Afr. J. Biotechnol., 9(52): 8944-8954.

- Burtis CA, Ashwood E, Bruns D (2006). Tietz textbook of clinical chemistry and molecular diagnostics. $4^{\text {th }} \mathrm{ed}$, Elsevier saunders, pp. 942-956.

-Duncan DB (1955). Multiple range and multiple F tests. Biometrics, 1: 11. https://doi.org/10.2307/3001478

-El-Garhy GM, Abd El-Mola AM, Azzaz HH, Mousa GA (2020b). Influence of using pectinase enzymes in the ration on nutrient digestibility, blood chemistry, milk composition and economics of lactating buffaloes. J. Anim Health Prod., 8(4): 158-167.

-E1-Garhy GM, Azzaz HH, Abd El-Mola AM, Mousa GA (2020a). Fungal pectinase production optimization and its application in buffaloe's diets degradation. Int. J. Zoo Anim. Biol., 3(1): 199. https://doi.org/10.23880/IZAB-16000199

- Gaines WL (1928). The energy basis of measuring energy milk in dairy cows. Univ. Illinois Agric.,

- Goering HK, Van Soest PJ (1970). Forage fiber analysis (Apparatus, reagents, procedures and some applications). USDA. Agricultural handbook, Washington, DC, pp. 379.

- Howanitz PJ, Howantiz JH (1984). In Clinical diagnosis and management by laporatory methods, $17^{\text {th }}$ ed. J.B. Henry, ed, W.B. Saunders, Philadelphia, pp. 168.

-Kaneko JJ (1989). Clinical biochemistry of domestic animals $4^{\text {th }}$ ed., Academic Press, Inc. (USA).

-Khattab MSA, El-Bltagy EA, Abd El-Tawab AM, Matloup OH, Morsy TA, Azzaz HH, Abdou MM (2019). Productive performance of lactating buffaloes fed ration containing date seed and fibrolytic enzymes J. Appl. Sci., 19(3): 241246. https://doi.org/10.3923/jas.2019.241.246

- Kholif AE, Kassab AY, Azzaz HH, Matloup OH, Hamdon HA, Olafadehan OA, Morsy TA (2018). Essential oils blend with a newly developed enzyme cocktail works synergistically to enhance feed utilization and milk production of Farafra ewes in the subtropics. Small Rumin. Res., 161: 43-50. https://doi.org/10.1016/j.smallrumres.2018.02.011

-Kholif AM, Kasem JM, Bayoumi HM, Zaglool AH (2016). Response of lactating buffaloes to fibrolytic enzymes and their influence on milk and cheese properties. Egypt. J. Nutr. Feeds, 19(3): 385-397. https://doi.org/10.21608/ ejnf.2016.74938

- Mandels M, Hontz L, Nystrom J (1974). Enzymatic hydrolysis of waste cellulose. Biotech. Bioeng., 16: 1471. https://doi. org/10.1002/bit.260161105

- Miller GL (1972). Use of dinitrosalicyclic acid reagent for determination of reducing sugar. Biotechnol. Bioeng. Symp., 5: 193-219.

- Mohamed DEDA, Borhami, BE, El-Shazly KA, Sallam SMA (2013). Effect of dietary supplementation with fibrolytic enzymes on the productive performance of early lactating dairy cows. J. Agric. Sci., 5: 146-155. https://doi. org/10.5539/jas.v5n6p146

- Morgavi DP, Beauchemin KA, Nsereko V, Rode LM, Iwaasa AD, Yang WZ, McAllister, TA, Wang Y (2000). Synergy between ruminal fibrolytic enzymes and enzymes from Trichoderma longibrachiatum. J. Dairy Sci., 83: 1310-1321. https://doi.org/10.3168/jds.S0022-0302(00)74997-6

-Morsy TA, Kholif AE, Kholif SM, Kholif AM, Sun X, Salem AZM (2016). Effects of two enzyme feed additives on digestion and milk production in lactating Egyptian buffaloes. Ann. Anim. Sci., 16: 209-222. https://doi. org/10.1515/aoas-2015-0039

- NRC (1985). Nutrient requirement of sheep. National academy of science, national research council. Ashington, D.C., USA.

- Reitman S, Frankel S (1957). A colorimetric method for the determination of serum glutamic oxalacetic and glutamic pyruvic transaminases. Am. J. Clin. Pathol., 28: 56-63. https://doi.org/10.1093/ajcp/28.1.56

- Richard A, Mc Pherson M.D, Matthew R, Pincus MD (2011). Henry's clinical diagnosis and measurement by laboratory methods, 22 ${ }^{\text {nd }}$., W.B. Saunders and Co., Philadelphia PA. pp. 260.

- Smith EJ (1996). An industrial application of cellulases. J. Biotechnol. Bioeng., 73: 68-83.

- Soares MN, Silva R, Gomes E (1999). Screening of bacterial 
strains for pectinolytic activity characterization of the pgase produced by Bacillus species. Rev. Microbiol., 30: 229-303. https://doi.org/10.1590/S0001-37141999000400002

- Spierto FW, McNeil ML, Burtis CA (1979). The effect of temperature and wavelength on the measurement of creatinine with the jaffe procedure. Clin. Biochem., 12: 1821. https://doi.org/10.1016/S0009-9120(79)90032-8

-SPSS (2007). Statistical package for social science, SPSS Inc., Chicago, IL, USA Copyright $(\mathrm{C}$ for Windows, version 16.0.

-Tirado-González DN, Miranda-Romero LA, RuízFlores A, Medina-Cuéllar SE, Ramírez-Valverde $\mathrm{R}$ and TiradoEstrada G (2018). Meta-analysis: Effects of exogenous fibrolytic enzymes in ruminant diets. J. Appl. Anim. Res.,
46(1): 771-783. https://doi.org/10.1080/09712119.2017.1 399135

-Van Keulen JV, Young BA (1977). Evaluation of acid insoluble ash as a natural marker in ruminant digestibility studies. J. Anim. Sci., 44: 282. https://doi.org/10.2527/ jas1977.442282x

-Vinici JL, Bateman HG., Bhat MK, Clark JH, Erdman RA, Phipps RH, Van Amburgh ME, Hartnell GF, Hintz RL, Hard DL (2003). Effect of feeding supplemental fibrolytic enzymes or soluble sugars with malic acid on milk production. Dairy Sci., 86: 576. https://doi.org/10.3168/jds. S0022-0302(03)73636-4 